\title{
IS THERE A SUSTAINABLE FUTURE FOR WILDLIFE IN OIL PALM PLANTATIONS IN MALAYSIA?
}

\section{JAYASILAN MOHD-AZLAN and LISA LOK*}

\begin{abstract}
The oil palm scene is often highly debated and has been at the centre of controversy in the past decade. Dubbed the 'cash crop', many Third World tropical countries have seized the opportunity to mobilise oil palm at landscape levels to fuel the economy. However, many of these tropical countries are also rich in biodiversity and are home to many endemics and species of conservation importance. While it tackles economic issues like poverty alleviation, it comes at the cost of environmental destruction. Here we take a look at the potential values of forest fragments and wildlife-friendly practices in oil palm landscapes and their roles in conservation in Malaysia. As the demand for oil palm and its products are most likely to continue to grow, there is a need to look at how the relevant stakeholders will sustainably manage the increasing demand while improving biodiversity management.
\end{abstract}

Keywords: biodiversity, conservation, oil palm, policy, wildlife.

Received: 1 April 2020; Accepted: 20 September 2020; Published online: 23 November 2020.

\section{INTRODUCTION}

Malaysia is the second largest exporter of palm oil globally and the planted areas cover approximately 5.8 million hectares; approximately $17.57 \%$ of the total land area in Malaysia (FAO, 2011; MPOB, 2018). Agricultural landscapes are often lacking in biodiversity due to scarcity of resources (e.g., food and shelter) that would usually occur in natural environments (Chazdon et al., 2009). Therefore, not many native species, especially forest specialists, are able to thrive within the monoculture (Maddox, 2007; Edwards et al., 2010; Yap et al., 2010). As such, many recent publications comparing forest species and remnant species in monocultures only provide the extent of species and ecosystem function deficits due to this conversion.

The European Union's introduction of a palm oil biofuel ban, while designed to protect the future of biodiversity and aimed to thwart deforestation of rainforests in the tropics, may instead have dire

Institute of Biodiversity and Environmental Conservation, Universiti Malaysia Sarawak,

94300 Kota Samarahan, Sarawak, Malaysia.

E-mail: azlan@unimas.my implications. The ban's effectiveness has also been questioned by the International Union for the Conservation of Nature (IUCN, 2018), as the move will only increase production of other land-inefficient oil crops to compensate for the loss of market share and maintain existing oil palm plantations, which acts as a displacement rather than a prevention of global biodiversity losses resulting from oil palm. Palm oil-producing countries will find alternative markets and even compensate profit loss by increasing sales to importers such as China, India, and other countries which are not as committed as the European Union to sustainable sourcing. This, in turn, may weaken the implementation of palm oil sustainability certification programmes.

On the 10 June 2019, the Delegated Act was passed by the European Union Parliament to ban and restrict palm oil biofuel imports by 2030 (Ching, 2019). The passing of the Delegated Act disregards the commitments of certification schemes such as the Roundtable for Sustainable Palm Oil (RSPO) and the Malaysian Sustainable Palm Oil (MSPO) and hampers efforts to ensure that the production of oil palm is as environmentally sustainable as possible. The key issue for biodiversity loss is 
deforestation, which has now been addressed within the certification scheme of RSPO (zerodeforestation pledge), while MSPO prohibits planting on highly biodiverse lands. The RSPO certification programme also lists the protection of forest fragments within oil palm plantations as part of its principles and criteria (RSPO, 2018). However, the effectiveness of these forest remnants in terms of biodiversity conservation has been given little evaluation (Edwards et al., 2010; Bernard et al., 2014).

MSPO was first launched in 2015 by the Malaysian government as a national standard in its commitment to fulfilling sustainability requirements. MSPO is strongly aligned with the existing national legal and regulatory requirements which proved the general principles for the establishment, implementation and improvement of sustainable practices in Malaysia (McInnes, 2017). MSPO is mandatory requirement for all Malaysian oil palm industry by 31 December 2019 (Sivanandam, 2017) providing traceability up to the plantation level.

Checks and balances in the form of strict regulation, auditing and ambiguity need to be addressed. The Malaysian government has recently given the extent for RSPO to publish maps of palm oil concessions, promoting better accountability and transparency within the supply chain and help curb deforestation and forest fires (Reuters, 2019).

\section{ASSOCIATED BIODIVERSITY PATTERNS INSIDE OIL PALM PLANTATIONS}

There is a great ecological disparity between natural forests compared to the oil palm monoculture as plantations are typically simplistic in structure; lower canopy height, little to no undergrowth, typically uniform in oil palm age composition, more prone to climatic fluctuations and have greater human disturbances (Turner and Foster, 2006; Corley and Tinker, 2008). Various studies have proven the monoculture landscape to be a poor habitat for most species (Tscharntke et al., 2005; Maddox, 2007; Fayle et al, 2010; Srinivas and Koh, 2016; Mandal and Raman, 2016). However, depending on the plantation's structural attributes (e.g. understory vegetation, epiphyte prevalence and presence of other crops), it may support local wildlife by providing additional resources such as food or shelter (Aratrakorn et al., 2006; Nájera and Simonetti, 2010; Jambari et al., 2012; Azhar et al., 2014; 2015a; Yahya et al., 2017). Proximity to forest patches have also been found to influence species richness within the oil palm landscape (Koh, 2008a; Edwards et al., 2010; Azhar et al., 2011; Lucey et al., 2014; Pardo et al., 2019; Knowlton et al., 2019).

\section{The Potential Values of Forest Fragments in the Oil} Palm Landscape

Forest fragments within the oil palm landscape are the last bastions of refuge for biodiversity within the oil palm landscape and should not be regarded as 'low value' for conservation (Mohd-Azlan et al., 2019a) (Figure 1). Studies on forest fragments within oil palm plantations have shown that fragments support subsets of species richness from contiguous forest and are to a certain extent comparable to some fragmented and isolated protected areas, e.g. MohdAzlan et al. (2019a, b) recorded 42 species of birds, 15 species of bats and 10 species of small mammals in a high conservation value (HCV) forest patch (116 ha) in an oil palm plantation in Miri, Sarawak, Malaysia compared to 62 species of birds recorded by Arif and Azlan (2014) in Gunung Gading National Park (4100 ha), 15 species of bats in Similajau National Park (8996 ha) (Kumaran et al., 2011), 17 species of small mammals in Lambir Hills National Park $(6952$ ha), 29 in Mulu National Park (52 864 ha) and 19 in Niah National Park (3140 ha) (Shazali et al., 2016). A study by Struebig et al. (2008) in the Krau landscape, Peninsular Malaysia found that forest fragments of $>300$ ha supported a considerable amount of bat diversity and that species assemblages in larger fragments resemble those in contiguous forests despite being surrounded by agriculture. Studies in Sabah, Malaysia by Brühl et al. (2003), Benedick et al. (2006), Edwards et al. (2010) and Lucey et al. (2014), also highlighted the importance of forest fragments in their ability to support substantial amount of forest species and should not be neglected. Arthropods (Denan et al., 2019), birds (Koh, 2008b; Maas et al., 2013), bats (Williams-Guillén et al., 2008; Phommexay et al., 2011; Maas et al., 2013) and mammals (Chua et al., 2016; Holzner et al., 2019) have demonstrated functional roles as biological control agents that may benefit plantation managements. Thus, protecting forest patches within and surrounding plantations can contribute to both biological conservation and plantation sustainability.

Restricted access to oil palm plantation from extrusion and excision may benefit some of the heavily hunted species. Forest fragments have also been shown to support or facilitate movement of megafauna species such as the Malayan Tiger, Asiatic Tapir and Malayan Sun Bear (Azhar et al., 2013; Bernard et al., 2014; Guharajan et al., 2018) which are also transient in nature to the oil palm matrix.

Studies on biodiversity reconcilement remain divided between land sharing (Fitzherbert et al., 2008; Koh, 2008a; Tawatao et al., 2014; Mohd-Azlan et al., 2019a, b; Pardo et al., 2019) and land sparing (Edwards et al., 2010; Phalan et al., 2011; Bernard et al., 2014; Yue et al., 2015; Wearn et al., 2017) approaches. However, these should not be mutually 
exclusive, and a combination may allow a balance to be achieved between the multifunctionality of monoculture landscape and management needs (Fischer et al., 2006; Matson and Vitousek, 2006; Grass et al., 2019). This, in turn may reduce production area which many small-scale plantations may not see this as a favourable option.

All types of forest fragments harbour some level of biological value (Figure 2), but the proportions depend on factors such as isolation, the encompassed vegetation matrix and patch size (Edwards et al., 2011), which in turn may influence the edge effect and species spill over. Existing oil palm plantations can never be restored to their original forested state once their rich biodiversity has already been lost. Stakeholders need to constantly embrace new environmental challenges and advances and continue to provide resources to support and facilitate the rehabilitation and enhancements of forest fragments within their care. Mitigation initiatives during replanting, such as leaving some old oil palm patches embedded with reforestation programmes, could create wilderness areas over time. This, in turn, can create wildlife corridors between existing forest patches to enable wildlife migration that may encourage gene flow between populations (Falcy and Estades, 2007; Koh, 2008a). The oil palm industry must be ready to contribute some of these production areas to reforestation, especially those that are close to forest patches or that provide critical connectivity among forest patches.

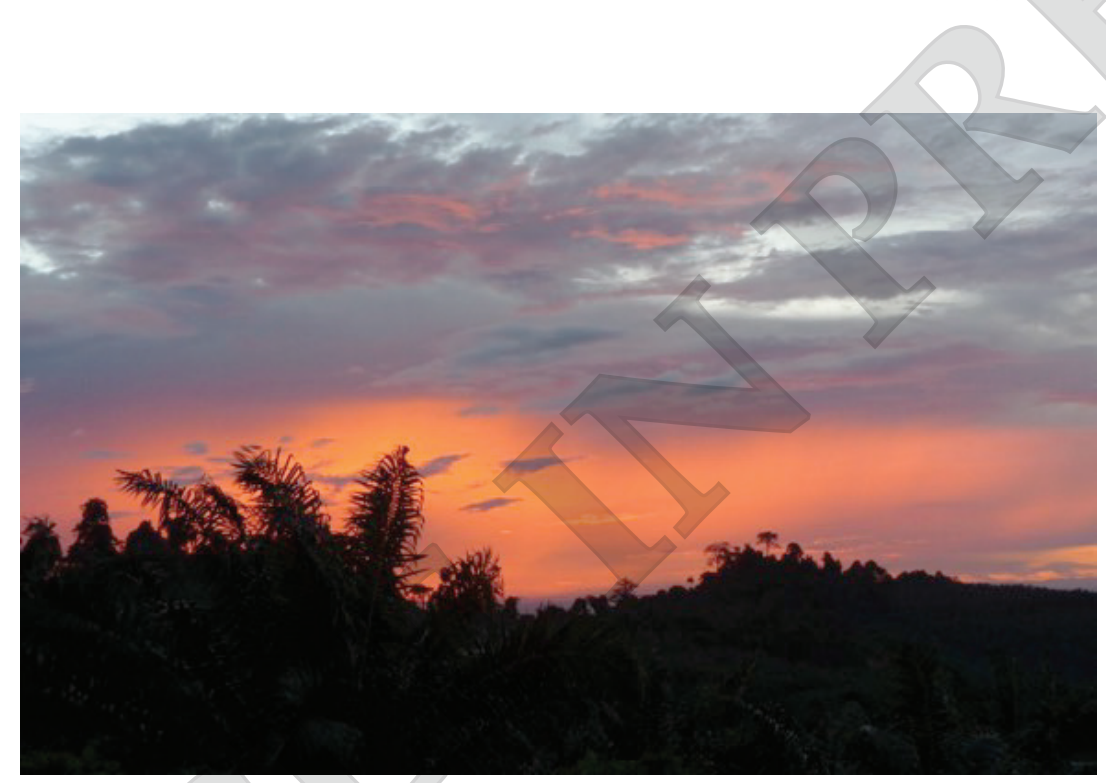

Figure 1. In silhouette against the evening sky, a forest fragment in an oil palm matrix that should not be regarded as low value for conservation.

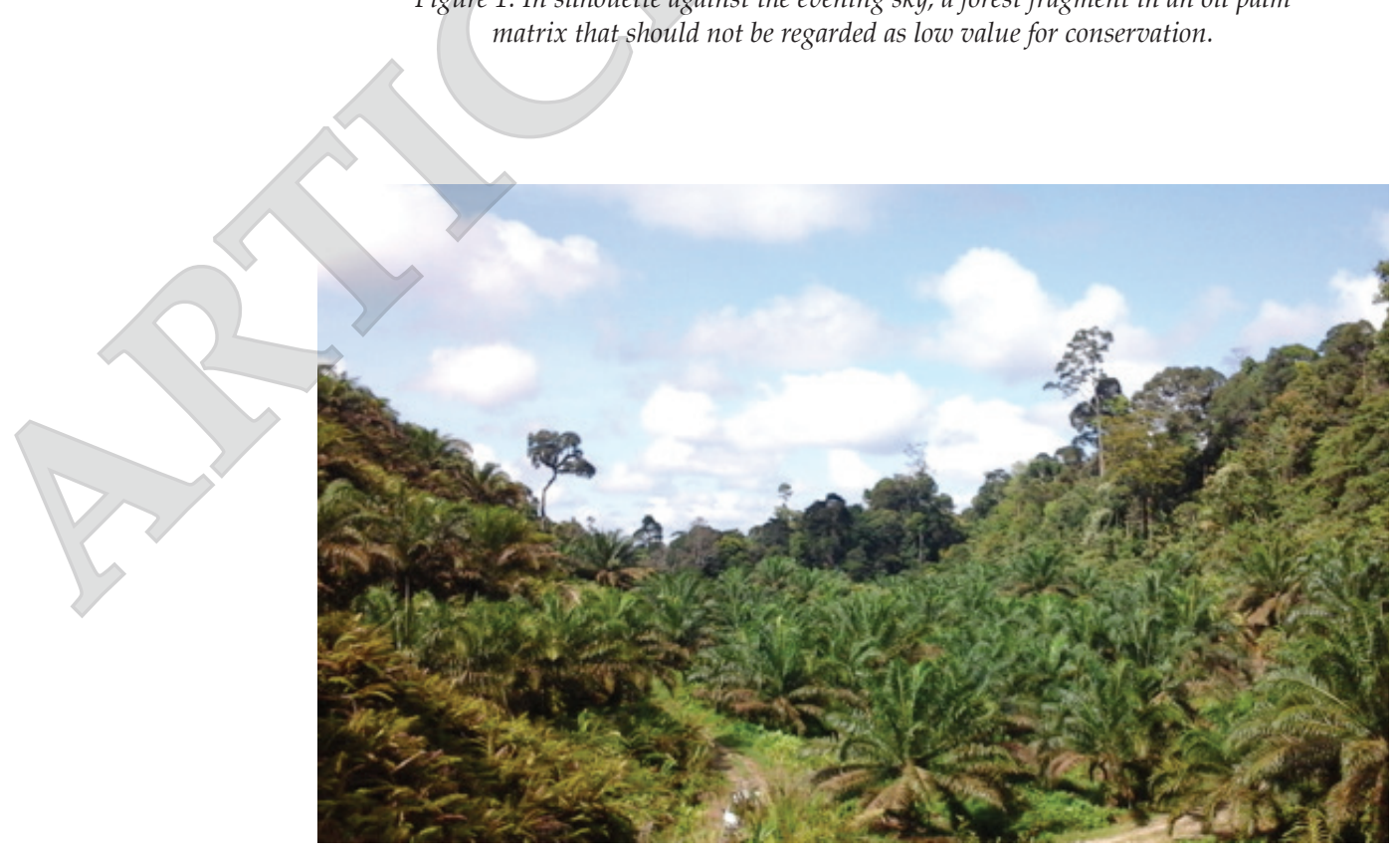

Figure 2. High conservation values forest (HCVF) (background) adjacent to the oil palm landscape may harbour some of the remnant species. 
There is also great potential in considering some $\mathrm{HCV}$ in oil palm plantation as Other Effective-based Conservation Measures (OECM) as part of the general conservation not only within the oil palm landscapes but externally as well. Potential OECM should be identified and reported by the relevant stakeholders as they can contribute to achieving the Aichi Biodiversity target (Target 11):

"By 2020, at least $17 \%$ of terrestrial and inland waters and $10 \%$ of coastal and marine areas, especially areas of particular importance for biodiversity and ecosystem services, are conserved through effectively and equitably managed, ecologically representative and well connected systems of protected areas and other effective area-based conservation measures, and integrated into the wider landscapes and seascapes" (Convention of Biological Diversity, 2018) and the national target (Target 6) (Ministry of Natural Resources and Environment, 2016), as their recognition can provide additional incentives for the stakeholders to provide and enact better protective measures for conservation.

These OECM are advantageous and recognised for promoting biodiversity conservation to the oil palm industry in a way as they can be potential corridors between protected areas wherever relevant, maintain and secure ecosystem services and support the recovery of threatened species (IUCN-WCPA Task Force on OECM, 2019).

\section{CONCLUSION}

By 2050, oil palm demand is expected to reach 120 156 million tonnes (RSPO, 2015). Malaysia direly needs to achieve a balance between economic growth and environmental sustainability. With nonexhaustive literature suggesting the negative impact of monoculture, government policies should ensure that no more forested land, including degraded secondary forest to be converted to supply the demand. Expansions can consider replacing of other non-economically viable agriculture. Future oil palm replantings need to be carefully and strategically designed to provide buffers around forests to facilitate connectivity (Scriven et al., 2019) as these areas are critical for biodiversity and ecosystem services. Additionally, to complement forested areas, the oil palm areas can be enhanced and made to be more hospitable to biodiversity by applying landscape management practices such as replacing chemical herbicides with integrating livestock (e.g. cattle) for undergrowth management (Tohiran et al., 2017; 2019), improve landscape heterogeneity and habitat complexity by implementing polyculture (Azhar et al., 2014; Ghazali et al., 2016; Ashraf et al., 2018; Atiqah et al., 2019) and reconfiguring patches of oil palm stands of different ages (Azhar et al., 2015b).
Therefore, instead of launching a ban, what we need the most right now is solidarity and collaboration at the global scale to tackle challenges together. A culture of sharing pioneering knowledge between researchers and industrial players is critical for formulating best practices across the industry for the sustainable management of oil palm plantation in our biodiversity-rich nation. By understanding the biological carrying capacity of forest fragments in oil palm plantations, we can suggest to managers different types of adaptive strategies that cater to improve the general biodiversity or species-specific actions to allow for a friendlier environment to biodiversity and subsequently support oil palm plantations to be more ecologically sustainable.

\section{ACKNOWLEDGEMENT}

The authors acknowledge the supports received from Wilmar International-PBB Oil Palms Berhad, Forest Department Sarawak, Sarawak Forestry Corporation, students and staff from the Institute of Biodiversity and Environmental Conservation, Universiti MalaysiaSarawak and Faculty of Resource Science and Technology, Universiti Malaysia Sarawak. We also appreciate the critical reviews made by the anonymous reviewers which improved the clarity and quality of this short communication.

\section{REFERENCES}

Aratrakorn, S; Thunhikorn, S and Donald, P F (2006). Changes in bird communities following conversion of lowland forest to oil palm and rubber plantations in southern Thailand. Bird Conserv. Int., 16(1): 71-82.

Arif, N A and Mohd-Azlan, J (2014). Diversity of birds captured by mist-netting in the understorey of Gunung Gading National Park, Sarawak, Borneo. Kukila, 17(2): 122-130.

Ashraf, M; Zulkifli, R; Sanusi, R; Tohiran, K A; Terhem, R; Moslim, R; Norhisham, A R; AshtonButt, A and Azhar, B (2018). Alley-cropping system can boost arthropod biodiversity and ecosystem functions in oil palm plantations. Agric. Ecosyst. Environ., 260: 19-26.

Atiqah, N; Yahya, M S; Aisyah, S; Ashton-Butt, A and Azhar, B (2019). Birds associated with different tree species and structures in oil palm agroforestry landscapes in Malaysia. Emu-Austral Ornithology, 119(4): 397-401.

Azhar, B; Lindenmayer, D B; Wood, J; Fischer, J; Manning, A; McElhinny, C and Zakaria, M (2011). The conservation value of oil palm plantation 
estates, smallholdings and logged peat swamp forest for birds. For. Ecol. Manag., 262(12): 2306-2315.

Azhar, B; Lindenmayer, D; Wood, J; Fischer, J; Manning, A; McElhinny, C and Zakaria, M (2013). Contribution of illegal hunting, culling of pest species, road accidents and feral dogs to biodiversity loss in established oil-palm landscapes. Wildlife Res., 40(1): 1-9.

Azhar, B; Puan, C L; Aziz, N; Sainuddin, M; Adila, N; Samsuddin, S; Asmah, S; Syafiq, M; Razak, S A; Hafizuddin, A and Hawa, A (2015a). Effects of in situ habitat quality and landscape characteristics in the oil palm agricultural matrix on tropical understorey birds, fruit bats and butterflies. Biodivers. Conserv., 24(12): 3125-3144.

Azhar, B; Puan, C L; Zakaria, M; Hassan, N and Arif, M (2014). Effects of monoculture and polyculture practices in oil palm smallholdings on tropical farmland birds. Basic Appl. Ecol., 15(4): 336-346.

Azhar, B; Saadun, N; Puan, C L; Kamarudin, N; Aziz, N; Nurhidayu, S and Fischer, J (2015b). Promoting landscape heterogeneity to improve the biodiversity benefits of certified palm oil production: Evidence from Peninsular Malaysia. Glob. Ecol. Conserv., 3(2015): 553-561.

Benedick, S; Hill, J K; Mustaffa, N; Chey, V K; Maryati, M; Searle, J B; Schilthuizen, M and Hamer, K C (2006). Impacts of rain forest fragmentation on butterflies in northern Borneo: Species richness, turnover and the value of small fragments. J. Appl. Ecol., 43(5): 967-977.

Bernard, H; Baking, E L; Giordano, A J; Wearn, O R and Ahmad, A H (2014). Terrestrial mammal species richness and composition in three small forest patches within an oil palm landscape in Sabah, Malaysian Borneo. Mamm. Study, 39(3): 141155.

Brühl, C A; Eltz, T and Linsenmair, K E (2003). Size does matter - Effects of tropical rainforest fragmentation on the leaf litter ant community in Sabah, Malaysia. Biodivers. Conserv., 12 (7): 13711389.

Chazdon, R L; Harvey, C A; Komar, O; Griffith, D M; Ferguson, B G; Martínez-Ramos, M; Morales, H; Nigh, R; Soto-pinto, L; Van Breugel, M and Philpott, S M (2009). Beyond reserves: A research agenda for conserving biodiversity in human-modified tropical landscapes. Biotropica, 41(2): 142-153.

Ching, J Y L; Yaman, I C; Khoon, K; Hong, C K and Melayong, G (2019). A case study into the sustainability journey and biodiversity conservation projects in Sarawak by Sarawak Oil Palms Berhad. J. Oil Palm Res. Vol. 31(3): 489-495.

Chua, M A; Sivasothi, N and Meier, R (2016). Population density, spatiotemporal use and diet of the leopard cat (Prionailurus bengalensis) in a humanmodified succession forest landscape of Singapore. Mamm. Res., 61(2): 99-108.

Corley, R H V and Tinker, P B (2008). The Oil Palm. Fourth edition. John Wiley \& Sons. 592 pp.

Denan, N; Wan Zaki, W M; Norhisham, A R; Sanusi, R; Nasir, D M; Nobilly, F; Ashton-Butt, A; Lechner, A M and Azhar, B (2019). Predation of potential insect pests in oil palm plantations, rubber tree plantations, and fruit orchards. Ecol. Evol., 10(2): 654-661.

Edwards, D P; Hodgson, J A; Hamer, K C; Mitchell, S L; Ahmad, A H; Cornell, S J and Wilcove, D S (2010). Wildlife-friendly oil palm plantations fail to protect biodiversity effectively. Conserv. Lett., 3(4): 236-242.

Edwards, D P; Larsen, T H; Docherty, T D; Ansell, F A; Hsu, W W; Derhé, M A; Hamer, K C and Wilcove, D S (2011). Degraded lands worth protecting: the biological importance of Southeast Asia's repeatedly logged forests. Proc. of the Royal Soc. B., 278(1702): 8290.

Falcy, M R and Estades, C F (2007). Effectiveness of corridors relative to enlargement of habitat patches. Conserv. Biol., 21(5): 1341-1346.

FAO (2011). Country profile - Malaysia. http:// www.fao.org/3/ca0216en/ CA 0216EN.pdf, accessed on 8 January 2020. 4 pp.

Fayle, T M; Turner, E C; Snaddon, L; Chey, V K; Chung, A Y; Eggleton, P and Foster, W A (2010). Oil palm expansion into rain forest greatly reduces ant biodiversity in canopy, epiphytes and leaf-litter. Basic Appl. Ecol., 11(4): 337-345.

Fischer, J; Lindenmayer, D B and Manning, AD (2006). Biodiversity, ecosystem function, and resilience: Ten guiding principles for commodity production landscapes. Front. Ecol. Environ., 4(2): 80-86.

Fitzherbert, E B; Struebig, M J; Morel, A; Danielsen, F; Brühl, C A; Donald, P F and Phalan, B (2008). How will oil palm expansion affect biodiversity? Trends Ecol. Evol., 23(10): 538-545.

Ghazali, A; Asmah, S; Syafiq, M; Yahya, M S; Aziz, N; Tan, L P; Norhisham, A R; Puan, C L; Turner, E C and Azhar, B (2016). Effects of monoculture and polyculture farming in oil palm smallholdings on 
terrestrial arthropod diversity. J. Asia-Pac. Entomol., 19(2): 415-421.

Grass, I; Loos, J; Baensch, S; Batáry, P; LibránEmbid, F; Ficiciyan, A; Klaus, F; Riechers, M; Rosa, J; Tiede, J and Udy, K (2019). Land-sharing/sparing connectivity landscapes for ecosystem services and biodiversity conservation. People and Nature, 1(2): 262-272.

Guharajan, R; Arnold, T W; Bolongon, G; Dibden, G H; Abram, N K; Teoh, S W; Magguna, M A; Goossens, B; Te Wong, S; Nathan, S K and Garshelis, D L (2018). Survival strategies of a frugivore, the sun bear, in a forest-oil palm landscape. Biodiverse. Conserv., 27(14): 3657-3677.

Holzner, A; Ruppert, N; Swat, F; Schmidt, M; Weiß, B M; Villa, G; Mansor, A; Sah, S A M; Engelhardt, A; Kühl, H and Widdig, A (2019). Macaques can contribute to greener practices in oil palm plantations when used as biological pest control. Curr. Biol., 29(20): 1066-1067.

IUCN (2018). Saying 'no' to palm oil would likely displace, not halt biodiversity loss - IUCN report. https://www.iucn.org / news/secretariat/201806/ saying-no-palm-oil-would-likely-displace-nothalt-biodiversity-loss---iucn-report, accessed on 30 October 2019. 3 pp.

IUCN-WCPA Task Force on OECMs (2019). Recognising and Reporting Other Effective Area-based Conservation Measures. IUCN, Gland, Switzerland. 36 pp.

Jambari, A; Azhar, B; Ibrahim, N L; Jamian, S; Hussin, A; Puan, C L; Noor, H M; Yusof, E and Zakaria, M (2012). Avian biodiversity and conservation in Malaysian oil palm production areas. J. Oil Palm Res. Vol. 24: 1277-1286.

Knowlton, J L; Mata-Zayas, E E; Ripley, A; Valenzuela-Cordova, B and Collado-Torres, R (2019). Mammal diversity in oil palm plantations and forest fragments in a highly modified landscape in southern Mexico. Front. for Glob. Change, 2: 67.

Koh, L P (2008a). Can oil palm plantations be made more hospitable for forest butterflies and birds? J. App. Ecol., 45(4): 1002-1009.

Koh, L P (2008b). Birds defend oil palms from herbivorous insects. Ecol. Appl., 18(4): 821-825.

Koh, L P; Levang, P and Ghazoul, J (2009). Designer landscapes for sustainable biofuels. Trends Ecol. Evol., 24(8): 431-438.
Kumaran, J V; Ketol, B; Marni, W; Sait, I; Mortada, M J; Khan, F A A; Har F P; Hall, L S and Abdullah, M T (2011). Comparative distribution and diversity of bats from selected localities in Sarawak. Borneo J. Resource Science and Technology, 1(1): 1-13.

Lucey, J M; Tawatao, N; Senior, M J; Chey, V K; Benedick, S; Hamer, K C; Woodcock, P; Newton, R J; Bottrell, S H and Hill, J K (2014). Tropical forest fragments contribute to species richness in adjacent oil palm plantations. Biol. Conserv., 169: 268-276.

Maas, B; Clough, Y and Tscharntke, T (2013). Bats and birds increase crop yield in tropical agroforestry landscapes. Ecol. Lett., 16(12): 1480-1487.

Maddox, T (2007). The Conservation of Tigers and Other Wildlife in Oil Palm Plantations: Jambi Province, Sumatra, Indonesia (October 2007). Zoological Society of London. 62 pp.

Mandal, J and Shankar Raman, T R (2016). Shifting agriculture supports more tropical forest birds than oil palm or teak plantations in Mizoram, northeast India. Condor., 118(2): 345-359.

Matson, P A and Vitousek, P M (2006). Agricultural intensification: Will land spared from farming be land spared for nature? Conserv. Biol., 20(3): 709-710.

McInnes, A (2017). A Comparison of Leading Palm Oil Certification Standards. http:/ / www. forestpeoples. org / sites / default / files / documents / Palm \% 20Oil\% 20Certification $\%$ 20Standards_lowres_spre ads. pdf, accessed on 18 October 2018. 45 pp.

Ministry of Natural Resources and Environment (2016). National Policy on Biological Diversity 2016-2025. http: / / www.kats.gov.my / ms-my / PustakaMedia / Penerbitan/ National\% 20Policy $\% 20$ on\% 20Biological\%20Diversity \% 202016-2025.pdf., accessed on 12 January 2020. 116 pp.

Mohd-Azlan, J; Fang, V A M; Kaicheen, S S; Lok, L; and Lawes, M J (2019a). The diversity of understorey birds in forest fragments and oil palm plantation, Sarawak, Borneo. J. Oil Palm Res. Vol. 31(3): 437-447.

Mohd-Azlan, J; Kaicheen, S S; Lok, L and Lawes, M J (2019b). The role of forest fragments in small mammal conservation in an oil palm plantation in northern Sarawak, Borneo. J. Oil Palm Res. Vol. 31(3): 422-436.

MPOB (2018). Overview of the Malaysian oil palm industry. http: / bepi.mpob.gov.my/images / overview / overview_of_industry_2018.pdf, accessed on 16 October 2018. 
Nájera, A and Simonetti, J A (2010). Can oil palm plantations become bird friendly? Agrofor. Syst., 80(2): 203-209.

Pardo, L E; Campbell, M J; Cove, M V; Edwards, W; Clements, G R and Laurance, W F (2019a). Land management strategies can increase oil palm plantation use by some terrestrial mammals in Colombia. Sci. Rep., 9(1): 1-12.

Phalan, B; Onial, M; Balmford, A and Green, R E (2011). Reconciling food production and biodiversity conservation: Land sharing and land sparing compared. Science, 333(6047): 1289-1291.

Phommexay, P; Satasook, C; Bates, P; Pearch, M and Bumrungsri, S (2011). The impact of rubber plantations on the diversity and activity of understorey insectivorous bats in southern Thailand. Biodivers. Conserv., 20(7): 1441-1456.

Reuters (2019). Indonesia urged to follow 'gamechanger' Malaysia on palm oil maps. https: / / www. nst.com.my/news/nation/2019/12 /54 7702/ indonesia-urged-follow-game-changer-malaysiapalm-oil-maps, accessed in November 2019.

RSPO (2015). A Shared Vision 100\% Sustainable Palm Oil in Europe: A Snapshot of National Initiatives. RSPO, Kuala Lumpur, Malaysia. 16 pp.

RSPO (2018). Principles and Criteria for Sustainable Palm Oil 2018. https://rspo.org/resources/ certification/rspo-principles-criteria-certification, accessed in October 2019.

Scriven, S A; Carlson, K M; Hodgson, J A; McClean, C J; Heilmayr, R; Lucey, J M and Hill, J K (2019). Testing the benefits of conservation set-asides for improved habitat connectivity in tropical agricultural landscapes. J. Appl. Ecol., 56(10): 22742285 .

Shazali, N; Khalik, M Z; Rahman, S H; Azhar, I; Khan, F A A; Tahir, N A; Murni, R; McArthur, E; Latip, N A; Rahman, M R A and Naharuddin, N (2016). Small mammals from Miri, north-eastern region of Sarawak, Malaysian Borneo: Note on new locality records. Check List, 12: 1.

Sivanandam, H (2017). MSPO certification mandatory by 2019. https: / / www.thestar.com.my / news / nation / 2017 / 02 / 25 / mspo-certificationmandatory-by-2019-govt-aims-for-sustainable-oilpalm-industry, accessed on 18 December 2019.

Srinivas, A and Koh, L P (2016). Oil palm expansion drives avifaunal decline in the Pucallpa region of Peruvian Amazonia. Glob. Ecol. Conserv., 7: 183-200.

Struebig, M J; Kingston, T; Zubaid, A; Mohd-Adnan, A and Rossiter, S J (2008). Conservation value of forest fragments to Palaeotropical bats. Biol. Conserv., 141(8): 2112-2126.

Tawatao, N; Lucey, J M; Senior; Benedick, S; Khen, C V; Hill, J K and Hamer, K C (2014). Biodiversity of leaf-litter ants in fragmented tropical rainforests of Borneo: The value of publically and privately managed forest fragments. Biodiverse. Conserv., 23(12): 3113-3126.

Tohiran, K A; Nobilly, F; Zulkifli, R; AshtonButt, A and Azhar, B (2019). Cattle-grazing in oil palm plantations sustainably controls understory vegetation. Agric. Ecosyst. Environ., 278: 54-60.

Tohiran, K A; Nobilly, F; Zulkifli, R; Maxwell, T; Moslim, R and Azhar, B (2017). Targeted cattle grazing as an alternative to herbicides for controlling weeds in bird-friendly oil palm plantations. Agron. Sustain. Dev., 37(6): 62.

Tscharntke, T; Klein, A M; Kruess, A; SteffanDewenter, I and Thies, C (2005). Landscape perspectives on agricultural intensification and biodiversity-ecosystem service management. Ecol. Lett., 8(8): 857-874.

Turner, E and Foster, W A (2006). Assessing the influence of bird's nest ferns (Asplenium spp.) on the local microclimate across a range of habitat disturbances in Sabah, Malaysia. Selbyana, 27(2): 195-200.

Wearn, O R; Rowcliffe, J M; Carbone, C; Pfeifer, M; Bernard, H and Ewers, R M (2017). Mammalian species abundance across a gradient of tropical landuse intensity: A hierarchical multi-species modeling approach. Biol. Conserv., 212: 162-171.

Williams-Guillén, K; Perfecto, I and Vandermeer, J (2008). Bats limit insects in a neotropical agroforestry system. Science, 320(5872): 70-70.

Yahya, M S; Syafiq, M; Ashton-Butt, A; Ghazali, A; Asmah, S and Azhar, B (2017). Switching from monoculture to polyculture farming benefits birds in oil palm production landscapes: Evidence from mist netting data. Ecol. Evol., 7(16): 6314-6325.

Yue, S; Brodie, J F; Zipkin, E F and Bernard, H (2015). Oil palm plantations fail to support mammal diversity. Ecol. Appl., 25(8): 2285-2292. 